\title{
Social defeat: Concept and measurement in a Hispanic population
}

\author{
Yanet Quijada,' Loreto Villagrán²
}

Facultad de Psicología, Universidad San Sebastián, Concepción, Chile.

2 Departamento de Psicología, Universidad de Concepción, Concepción, Chile.

\section{Correspondence:}

Yanet Quijada

Facultad de Psicología, Universidad de San Sebastián, Concepción, Chile. Lientur 1457,

Concepción, Región del Bío Bío,

Concepción, Chile.

Phone: +56 41 248-7565

Email: yanetquijada@gmail.com

Received: 15 June 2020

Accepted: 17 June 2020

Citation:

Quijada, Y., \& Villagrán, L. (2021). Social defeat: Concept and measurement in a Hispanic population. Salud Mental, 44(1), 11-16.

DOI: $10.17711 /$ SM.0185-3325.2021.003

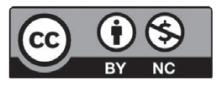

\begin{abstract}
Introduction. Social defeat (SD) is defined as a feeling of having lost the fight leading to a loss of valuable status or of important personal goals, and has been associated to depression and suicidal behavior, among other disorders. Furthermore, it has been proposed as a mediating variable between social and clinical elements. Objective. To adapt and validate a Spanish version of the Defeat Scale. Method. A back translation into Spanish was carried out. SD, hopelessness, and social well-being were measured in 546 university students (Mean age $=20.93$ years, $S D=2.98 ; 68.7 \%$ females). Results. An exploratory factor analysis offered a two-dimension structure in the scale made up by the dimension defeat and triumph. A confirmatory factor analysis found good fit indicators for the two-dimension model $\left(d f=89 ; \chi^{2}=188.96 ; C F I=.942 ; R M S E A=.061\right.$; $I F I=.943$ ). Both dimensions present good internal consistency (Cronbach's alpha $>.70)$. SD was associated to higher levels of hopelessness and lower levels of social well-being. Discussion and conclusion. The Spanish version of the Defeat Scale presents good psychometric properties. Its use can help deepen the understanding of psychopathological phenomena and their link to social elements within the context of Spanish speaking countries.
\end{abstract}

Keywords: Linguistic adaptation, psychometric, depression, hopelessness, social well-being.

\section{RESUMEN}

Introducción. La derrota social (DS) se define como la sensación de lucha fallida en relación con una pérdida de estatus valioso o de metas personales importantes, y se ha relacionado con depresión y conducta suicida, entre otros trastornos. Además, ha sido propuesta como una variable mediadora entre elementos sociales y clínicos. Objetivo. Adaptar y validar al español la Defeat Scale. Método. Se realizó una traducción inversa para obtener la versión al español de la escala. Con la participación de 546 estudiantes universitarios $(M=20.93$ años, $D S=2.98 ; 68.7 \%$ mujeres), se evaluaron DS, desesperanza y bienestar social. Resultados. El análisis factorial exploratorio encontró una estructura de dos dimensiones, compuesta por una dimensión de derrota y otra de triunfo. El análisis factorial confirmatorio encontró buenos indicadores de ajuste para el modelo de dos dimensiones $\left(d f=89 ; \chi^{2}=188.96 ; C F I=.942 ; R M S E A=.061 ; I F I=.943\right)$. Ambas dimensiones presentaron buena consistencia interna $(\alpha>.70)$. La DS se asoció con mayores niveles de desesperanza y menores niveles de bienestar social. Discusión y conclusión. La versión al español de la Defeat Scale presenta buenas propiedades psicométricas. Su uso puede ayudar a profundizar la comprensión de psicopatologías y su relación con elementos sociales en países de habla hispana.

Palabras clave: Adaptación lingüística, psicométrica, depresión, desesperanza, bienestar social. 


\section{INTRODUCTION}

The social defeat construct has received a large amount of empirical support towards the understanding of depression, anxiety, post-traumatic stress (Siddaway, Taylor, Wood, \& Schulz, 2015; Taylor, Gooding, Wood \& Tarrier, 2011), and even risk of psychosis (Selten, van der Ven, Rutten \& Cantor-Graae, 2013). Furthermore, it has been integrated into explanatory models of suicidal behavior; such is the case of the Integrated motivational-volitional model of suicidal behavior (IMV, O'Connor, 2011). Social defeat is defined as the feeling of a failed fight regarding a loss of valuable status or of important personal goals (Gilbert \& Allan, 1998), or regarding a feeling of being less apt in order to achieve said goals (Gilbert, 2005; 2007). It holds the evolutionary approach towards depression as well as elements of social comparison as its basis. These approaches propose that human beings, as other primates, are sensitive to recognizing social hierarchies because they offer information about available resources and the probability of achieving them, which in turn constitutes a basic motivation for survival (Price, 1972). Individuals who perceive themselves as having low social status would have low expectations of obtaining what they need for themselves as well as for their group, they would lower their level of motivation in order to leverage frustration, and would avoid conflict with those more powerful than them by displaying submissive behavior which is in turn facilitated by physiological processes. Therefore, following this approach, depressive manifestations are conceptualized as defensive responses to the perception of low social status.

The concept of social defeat compliments the evolutionary approach with an individual component by proposing that human beings develop their own psychological hierarchy of goals and objectives. Thus, the person is conscious of his or her social status within the context of his or her goals. It is worth mentioning that in non-pathological conditions, unfavorable social comparison implies accepting defeat, temporarily experiencing its consequences (submission, lower motivations, hormonal reaction) to later redirect motivation and behaviors towards new goals (Sloman, Gilbert, \& Hasey, 2003). However, when unable to overcome defeat, a psychopathological condition would arise, specifically, being trapped in the feeling of defeat and chronically suffering its consequences: cognitive strategies of self-inefficacy, behavioral strategies of hypervigilance or inhibition, and affective strategies of reduction of positive affect (Siddaway et al., 2015; Griffiths, Wood, Maltby, Taylor, \& Tai, 2014).

The Defeat Scale developed by Gilbert and Allan (1998) is, until now, the most validated scale to assess social defeat. In their validation study with university students and patients suffering from depression, the authors found a one-dimension configuration of the construct, with high reliability and an association to higher level of depressive symptomatology, and hopelessness (Gilbert \& Allan, 1998). Similar results were found in the validation in Latin American populations, specifically in its Portuguese version (Carvalho, Pinto-Gouveia, Castilho, Pimentel, \& Maia, 2011). To our knowledge, so far there are no Spanish validation data published.

By capturing feelings linked to unfavorable social comparison, it has been proposed that social defeat could act as a mediator between a context of social inequality and the psychological unrest of the people who inhabit it (Quijada, Villagrán, Vaccari, Reyes, \& Gallardo, 2018). Specifically, Chile has presented deterioration in some mental health indicators, e.g., $21.1 \%$ of Chilean adults claim having been diagnosed with depression at some point in their lives (Ministerio de Salud de Chile, 2014). Moreover, suicide numbers in Chile increased by $54.9 \%$ between 1995 and 2009 (Organization for Economic Cooperation and Development [OECD], 2015a). If we consider Chile to have the same markedly social inequality in the last decades (Espinoza, Barozet, \& Méndez, 2013; OECD, 2015b), the assessment of social defeat could improve the understanding of its population's mental health and could validate the integration of socio-communal components in prevention and intervention strategies. Therefore, our goal was to adapt and validate the Defeat Scale into Spanish within the Chilean context, taking into account its link to hopelessness and social well-being.

\section{METHOD}

\section{Participants}

The total sample was comprised 546 students from the Universidad San Sebastián de Concepción (USS) and the Universidad Católica de la Santísima Concepción. Two groups were randomly created stratifying by age and sex. The first sample $\left(\mathrm{N}_{1}=273 ;\right.$ Mean age $=20.89$ years; $S D=2.71 ; 70.4 \%$ female) was used for exploratory factor analysis (EFA). The second sample $\left(\mathrm{N}_{2}=273\right.$; Mean age $=20.97$ years, $S D=$ $3.23 ; 70.0 \%$ female) was used for confirmatory factor analysis (CFA). Both samples included Psychology, Odontology, Pedagogy, and Medical students. The inclusion criterion was being older than 18 , and the exclusion criterion was presenting any known form of difficulty to respond autonomously and in the format proposed.

\section{Instruments}

\section{The Defeat Scale (Gilbert \& Allan, 1998)}

This scale has 16 items that assess the frequency of perceptions of having lost the fight, defenselessness, or loss of status during the last week. Items are Likert-scaled and include options between $0=$ rarely and $4=$ always. Previous studies show good reliability ( $\alpha=.94$; Taylor et al., 2011). 
Beck Hopelessness Scale, BHS (Beck, Weissman, Lester, \& Trexler, 1974)

This scale is comprised of 20 dychotomous (true or false) items that measure attitudes towards expectations. It has been validated in Spanish and used in Chilean mental health studies ( $\alpha=.97$; Valdivia, Silva, Sanhueza, Cova, \& Melipillan, 2015). In the present study, Cronbach's Alpha was $\alpha=.84$.

Social Well-Being Questionnaire SW (Keyes, Shmotkin, \& Ryff, 2002; Blanco \& Díaz, 2006)

This instrument is comprised of 25 items grouped into five dimensions that measure social integration, social acceptance, social contribution, social actualization, and social coherence. Items are 5-choice Likert-scaled (1: completely disagree; 5: completely agree). In the present study, Cronbach's Alpha for each dimension was: integration $\alpha=.77$, acceptance $\alpha=.79$, contribution $\alpha=.70$, actualization $\alpha=.60$ y coherence $\alpha=.53$.

\section{Procedure}

The study was conducted during the first and second semesters of 2017. The cultural and linguistic adaptation of the scale was based on the back translation method (Brislin, 1986) and the International Test Commission (Muñiz, Elosua, \& Hambleton, 2013). A pilot study was carried out during the first semester of 2017 with university students and pertinent modifications were made. The initial contact with the participants was made by the first author; and thereupon, together with the co-author, six Psychology-degree senior students were trained to conduct the questionnaires. The questionnaire was applied voluntarily in a group setting (pencil and paper format). All participants signed their informed consent and received no payment of any kind.

\section{Statistical analysis}

An exploratory factor analysis (EFA) was carried out using the results from the first sample in order to study the internal structure of the scale. Data quality was checked using Kaiser-Meyer-Olkin's (KMO) test. EFA specifications were: principal axis factoring extraction method with direct oblimin rotation assuming correlated factors (Izquierdo Alfaro, Olea Díaz, \& Abad García, 2014; Jennrich \& Sampson, 1966). The number of factors retained was determined through parallel analysis by using O'connor's (2000) SPSS syntax.

Data from the second sample were used to carry out a CFA with the objective of verifying the proposed model. Parameter estimation was obtained using the maximum likelihood method taking into account fit index recommendations by Izquierdo Alfaro et al. (2014) and Abad, Olea, Ponsoda, and García (2011). Adequate chi-square $\left(\chi^{2}\right)$ val- ues were set to be under 3 . The absolute measure of fit indicator was the Root Mean Square error of Approximation (RMSEA). Values below .05 indicated good fit, and values between .06 and .08 indicated reasonable fit. Comparative fit was analyzed using the Incremental Fit Index (IFI) and the Comparative Fit Index (CFI). Values above .90 indicate acceptable fit, and values above .95 indicate excellent fit. All data analyses were carried out using IBM SPSS 23 and AMOS. All subjects with missing data were deleted. The variables in this study are ordinal but are treated as scale variables, a procedure used when Likert scale items have at least five response categories (Wu \& Leung, 2017). This is the same procedure used by the original authors of the scale (Gilbert \& Allan, 1998), as well as by the authors who validated its Portuguese version (Carvalho et al., 2011). The sample sizes followed the recommendations made by Mundfrom, Shaw, and Ke (2005), who point out that a sample of 100 can be sufficient in a factorial analysis when factorial weights are high (between .6 and .8). Statistical analysis was carried out by co-author.

\section{Ethical considerations}

The study was approved by the Scientific Ethics Committee of the USS. Authorization from the original authors was obtained for the translation.

\section{RESULTS}

Horn's parallel analysis suggested retaining two factors for $\mathrm{SD}$. The data showed good indexes for EFA $(\mathrm{KMO}=.92)$ and explained $49.59 \%$ of the sum of squared loadings. Table 1 shows the EFA pattern matrix. Factor I has 13 items with loadings between .33 and .80 . These items express cognitions or assessments which are typical of SD (e.g., item 11: "I feel completely knocked out of action") and match the original proposal. Therefore, the name "social defeat" was kept for this dimension. Factor II has 3 items with loadings between .44 and .78. These items express positive assessments (e.g., item 9: "I feel able to deal with whatever life throws at me"). Therefore, this dimension was named "personal triumph." Item 1 was the only one to show crossed loadings in both dimensions. Interfactor correlation was negative $(r=-.423, p \leq .05)$.

CFA was carried out using data from the second sample. Although a second dimension appeared in the previous scale validations, the authors have decided on a one-dimension solution. This decision was based on the screen test (Gilbert \& Allan, 1998) and, also, in order to force a one factor solution such as the original authors did (Carvalho et al., 2011). This study aimed to explore and confirm the two-factor solution found in the EFA, taking into account the suggestions made by the authors of the Portuguese vali- 
Table 1

Pattern matrix for social defeat

\begin{tabular}{lc}
\hline & \multicolumn{2}{c}{ Factor } \\
\cline { 2 - 2 } Item & $I$ \\
\hline 11. Me siento completamente fuera de combate [I feel completely knocked out of action] & .80 \\
14. Me siento acabado [I feel down and out] & .78 \\
12. Siento que soy uno más de los perdedores en la vida [I feel that I am one of life's losers] & .77 \\
10. Siento que he tocado fondo [I feel that I have sunk to the bottom of the ladder ] & .75 \\
13. Siento que me he dado por vencido [I feel that I have given up ] & .75 \\
16. Siento que no me quedan fuerzas para luchar [I feel that there is no fight left in me] & .70 \\
8. Siento que la confianza en mí mismo ha sido destruida [I feel that my confidence has been knocked out of me] \\
15. Siento que he perdido batallas importantes en la vida [I feel I have lost important battles in life ] \\
6. Siento que la vida me ha tratado a golpes [I feel that life has treated me like a punchbag ] \\
5. Siento que he perdido mi posición en el mundo [I feel that I have lost my standing in the world] \\
3. Me siento derrotado por la vida [I feel defeated by life] \\
7. Me siento impotente [I feel powerless ] \\
1. Siento que no he hecho nada con mi vida [I feel that I have not made it in life] \\
4. Me siento un ganador [I feel that I am basically a winner] \\
2. Siento que soy una persona exitosa [I feel that I am a successful person] \\
9. Me siento capaz de enfrentar cualquier cosa que la vida me envíe [I feel able to deal with whatever life throws at me] \\
Cronbach's $\alpha$
\end{tabular}

Table 2

CFA Fit indicators for social defeat (maximum likelihood)

\begin{tabular}{lccccc}
\hline Model & $X^{2}$ & $d f$ & CFI & IFI & RMSEA \\
\hline $\begin{array}{l}\text { One-dimension } \\
\text { (original model) }\end{array}$ & 384.550 & 104 & .852 & .853 & .095 \\
$\begin{array}{l}\text { Two-dimension } \\
\text { (proposed model) }\end{array}$ & 188.96 & 89 & .942 & .943 & .061 \\
\hline
\end{tabular}

dation who considered that "triumph" items may not be the opposite of the "defeat" items (e.g., "feeling like a winner," item 4 , is not the opposite of "feeling defenseless," item 7).

Table 2 shows that the two-dimension model had better fit results than the one-dimension model as per CFI, IFI, and RMSEA. The two-dimension model chi-square value was $\chi^{2}=$ $188,96, d f=89$, which is to be accepted due to sample size.

\section{Reliability}

The social defeat and personal triumph dimensions showed good consistency values (Cronbach's alpha is above .70 for both).

\section{Convergent and divergent validity}

Table 3 shows the correlations between SD dimensions with Hopelessness and the Social Well-being dimensions. All correlations were significant and were within theoretical expectations. Convergent validity was found between SD and hopelessness, and divergent validity was found between SD and social well-being. Results for "social triumph" were also as expected.

\section{DISCUSSION AND CONCLUSION}

The internal structure found comprised by two dimensions matched the preliminary results of the Portuguese validation and findings of the original authors. The persistence of the two-dimension model holds two possible explanations: firstly, the method effect presented by the original authors; and secondly, that the "triumph" or "success" dimension comprised of reverse SD items cannot be explained simply as a negative version of experiences of defeat. Assessing how defeated a person feels may be set in certain personal goals,

Table 3

Correlations between Beck's Hopelessness Scale (BHS), Social Well-Being dimensions, and dimensions in the DS scale

\begin{tabular}{|c|c|c|c|c|c|c|}
\hline & \multicolumn{6}{|c|}{ Social Well-Being } \\
\hline & $B H S$ & Integration & Acceptance & Contribution & Actualization & Coherence \\
\hline F1 SD Defeat & $.695^{\star *}$ & $-.557^{\star \star}$ & $-.379^{\star \star}$ & $-.495^{\star *}$ & $-.348^{* *}$ & $-.404^{* *}$ \\
\hline F2 SD Triumph & $-.391^{* *}$ & $.586^{* *}$ & $.263^{* *}$ & $.523^{\star *}$ & $.150^{*}$ & $.318^{* *}$ \\
\hline
\end{tabular}

Notes: ${ }^{*} p<.05 ;{ }^{* *} p<.01$ 
whereas feelings of triumph may be felt in relation to other goals. As an example, traumatic experiences have been found at the same time as well-being experiences within the context of violence and forced displacements (Abello-Llanos et al., 2009). Furthermore, resilience evidence, such as humour, creativity, a sense of contributing to the community among others, has all been found in women who have suffered abuse (Sánchez, 2015). Therefore, these results must be taken cautiously until further analyses that explore the presense of the method effect are carried out, such as the suggested methods by Tomás, Sancho Requena, Oliver Germes, Galiana Llinares, and Meléndez Moral (2012), which include multitrait-multimethod matrix convergent-divergent validity analysis using correlated traits and correlated methods (CFA-CTCM).

Social defeat was associated to highler levels of hopelessness, which is aligned to previous studies (Gilbert \& Allan, 1998; Tarsafi, Kalantarkousheh, \& Lester, 2015). Hopelessness has been described as a predictive variable for suicide and has been found to be closely associated to depression. Therefore, the relationship between SD and hopelessness is consistent with psychological models for suicide (Barzilay \& Apter, 2014). In the present study, SD was associated to lower levels of social well-being. Although SD has been linked to abusive group dynamics such as bullying (Björkqvist, 2001; Meltzer, Vostanis, Ford, Bebbington, \& Dennis, 2011), its reverse association with perceptions of integration or communal contribution adds to the discussion about how socio-contextual variables affect psychological well-being and play a role in individual suffering (Quijada et al., 2018; Wood, Boyce, Moore, \& Brown, 2012).

One limitation of the present study is that the sample was comprised of university students. Although the socioeconomic distribution of the sample used is similar to that of the one found in the Chilean population (Micin, Carreño, \& Urzúa, 2016), the use of university samples could limit the generalization of these results. It is suggested that future studies work with heterogeneous samples; a desirable feature that strengthens the reliability of a scale (Abad et al., 2011).

Finally, the Spanish language adaptation of the Defeat Scale shows good psychometric properties with a two-dimension model, and has good fit and reliability results. Assessing SD within the Latin American context will allow for a further understanding of the link between this variable and aspects of mental health which are prevalent in this context, such as depression, as well as its ties to social elements.

\section{Funding}

This study was partially funded by CONICYT/FONDECYT $n^{\circ} 11170308$ and Dirección General de Investigación of Universidad San Sebastián. (No 2015-0062-I).

\section{Conflict of interest}

The authors declare they have no conflicts of interest.

\section{REFERENCES}

Abad, F., Olea, J., Ponsoda, V., \& García, C. (2011). Medición en ciencias sociales y de la salud. Madrid, España: Síntesis.

Abello-Llanos, R., Amarís-Macías, M., Blanco-Abarca, A., Madariaga-Orozco, C., Manrique-Palacio, K., Martínez-González, M., ... Díaz-Méndez, D. (2009). Bienestar y trauma en personas adultas desplazadas por la violencia política. Universitas Psychologica, 8(2), 455-470.

Barzilay, S., \& Apter, A. (2014). Psychological models of suicide. Archives of Suicide Research, 18(4), 295-312. doi: 10.1080/13811118.2013.824825

Beck, A. T., Weissman, A., Lester, D., \& Trexler, L. (1974). The measurement of pessimism: The Hopelessness Scale. Journal of Consulting and Clinical Psychology, 42(6), 861-865. doi: 10.1037/h0037562

Björkqvist, K. (2001). Social defeat as a stressor in humans. Physiology \& Behavior, 73(3), 435-442. doi: 10.1016/S0031-9384(01)00490-5

Blanco, A., \& Díaz, D. (2006). Orden social y salud mental: una aproximación desde el bienestar social. Clínica y Salud, 17(1), 7-29.

Brislin, R. W. (1986). The wording and translation of research instruments. In W. J. Lonner, \& J. W. Berry (Eds.). Field methods in cross-cultural research (pp. 137164). Newbury Park, CA: Sage.

Carvalho, S., Pinto-Gouveia, J., Castilho, P., Pimentel, P., \& Maia, D. (2011). Derrota - conceito e avaliação: Características psicométricas da versão portuguesa da Escala de Derrota (Defeat Scale). Psychologica, (54), 465-491. doi: 10.14195/1647-8606_54_18

Espinoza, V., Barozet, E., \& Méndez, M. L. (2013). Estratificación y movilidad social bajo un modelo neoliberal: El caso de Chile. Lavboratorio, (25), 169-191.

Gilbert, P. (2005). Social mentalities: A biopsychosocial and evolutionary reflection on social relationships. In Baldwin, M. W. (Ed.). Interpersonal cognition (pp. 299-335). New York, USA: Guilford.

Gilbert, P. (2007). Evolved minds and compassion in the therapeutic relationship. In Gilbert, P., \& Leahy, R. (Eds.). The therapeutic relationship in the cognitive behavioral psychotherapies (pp. 106-142). Hove, UK: Routledge.

Gilbert, P., \& Allan, S. (1998). The role of defeat and entrapment (arrested flight) in depression: An exploration of an evolutionary view. Psychological Medicine, 28(3), 585-598. doi: 10.1017/S0033291798006710

Griffiths, A. W., Wood, A. M., Maltby, J., Taylor, P. J., \& Tai, S. (2014). The prospective role of defeat and entrapment in depression and anxiety: A 12-month longitudinal study. Psychiatry Research, 216(1), 52-59. doi: 10.1016/j.psychres.2014.01.037

Izquierdo Alfaro, I., Olea Díaz, J., \& Abad García, F. J. (2014). Exploratory factor analysis in validation studies: Uses and recommendations. Psicothema, 26(3), 395-400. doi: 10.7334/psicothema2013.349

Jennrich, R. I., \& Sampson, P. F. (1966). Rotation for simple loadings. Psychometrika, 31(3), 313-323. doi: 10.1007/BF02289465

Keyes, C. L., Shmotkin, D., \& Ryff, C. D. (2002). Optimizing well-being: the empirical encounter of two traditions. Journal of Personality and Social Psychology, 82(6), 1007-1022. doi: 10.1037/0022-3514.82.6.1007

Meltzer, H., Vostanis, P., Ford, T., Bebbington, P., \& Dennis, M. S. (2011). Victims of bullying in childhood and suicide attempts in adulthood. European Psychiatry, 26(8), 498-503. doi: 10.1016/j.eurpsy.2010.11.006

Micin, S., Carreño, B., \& Urzúa, S. (2016). Caracterización, nivelación y acompañamiento académico para estudiantes de ingreso a la Educación Superior. In H. Lavados, \& R. Berríos (Eds.). Políticas para el desarrollo universitario: principios y evidencias (pp. 359-398). Santiago: Ediciones Universidad San Sebastián.

Ministerio de Salud de Chile. (2014). Indicadores básicos de salud. Departamento de Estadísticas e Información de Salud. Retrieved from https://repositoriodeis. minsal.cl/ContenidoSitioWeb2020/uploads/2018/12/IBS-2010-2014.pdf

Mundfrom, D. J., Shaw, D. G., \& Ke, T. L. (2005). Minimum sample size recommendations for conducting factor analyses. International Journal of Testing, 5(2), 159-168. doi: 10.1207/s15327574ijt0502_4

Muñiz, J., Elosua, P., \& Hambleton, R. K. (2013). Directrices para la traducción y adaptación de los tests (Segunda Edición). Psicothema, 25(2), 151-157. doi: 10.7334/psicothema2013.24

O'connor, B. P. (2000). SPSS and SAS programs for determining the number of components using parallel analysis and Velicer's MAP test. Behavior Research Methods, Instruments, \& Computers, 32(3), 396-402. doi: 10.3758/BF03200807 
O'Connor, R. C. (2011). The integrated motivational-volitional model of suicidal behavior. Crisis, 32(6), 295-298. doi: 10.1027/0227-5910/a000120

Organization for Economic Cooperation and Development [OECD]. (2015a). Suicide, in Health at a Glance 2015: OECD Indicators. Paris: OECD Publishing.

Organization for Economic Cooperation and Development [OECD]. (2015b). How's Life? 2015: Measuring Well-Being. doi: 10.1787/how_life-2015-graph87-en

Price, J. S. (1972). Genetic and phylogenetic aspects of mood variation. International Journal of Mental Health, 1(1-2), 124-144. doi: 10.1080/00207411.1972.11448570

Quijada, Y., Villagrán, L., Vaccari, P., Reyes, C., \& Gallardo, L. D. (2018). Social Inequality and Mental Health in Chile, Ecuador, and Colombia. Latin American Perspectives, 46(6), 92-108. doi: 10.1177/0094582X18803682

Sánchez, L. S. (2015). Resiliencia en violencia de género. Un nuevo enfoque para los/ las profesionales sanitarios/as. Journal of Feminist, Gender and Women Studies, (1), 103-113

Selten, J. P., van der Ven, E., Rutten, B. P., \& Cantor-Graae, E. (2013). The social defeat hypothesis of schizophrenia: An update. Schizophrenia Bulletin, 39(6), 1180-1186. doi: 10.1093/schbul/sbt134

Siddaway, A. P., Taylor, P. J., Wood, A. M., \& Schulz, J. (2015). A meta-analysis of perceptions of defeat and entrapment in depression, anxiety problems, posttraumatic stress disorder, and suicidality. Journal of Affective Disorders, 184, 149-159. doi: 10.1016/j.jad.2015.05.046

Sloman, L., Gilbert, P., \& Hasey, G. (2003). Evolved mechanisms in depression: The role and interaction of attachment and social rank in depression. Journal of Affective Disorders, 74(2), 107-121. doi: 10.1016/S0165-0327(02)00116-7
Tarsafi, M., Kalantarkousheh, S. M., \& Lester, D. (2015). The defeat-entrapment theory versus Beck's hopelessness theory of depression and suicidality: A crossnational analysis in Iran and the United States. International Journal of Social Psychiatry, 61(8), 777-780. doi: 10.1177/0020764015583921

Taylor, P. J., Gooding, P., Wood, A. M., \& Tarrier, N. (2011). The role of defeat and entrapment in depression, anxiety, and suicide. Psychological Bulletin, 137(3), 391-420. doi: 10.1037/a0022935

Tomás, J. M., Sancho Requena, P., Oliver Germes, A., Galiana Llinares, L., \& Meléndez Moral, J. C. (2012). Efectos de método asociados a ítems invertidos vs. ítems en negativo. Revista Mexicana de Psicología, 29(2). 105-115. Recuperado de http://www.redalyc.org/articulo.oa?id=243030190001

Valdivia, M., Silva, D., Sanhueza, F., Cova, F., \& Melipillan, R. (2015). Suicide attempts among chilean adolescents. Revista Médica de Chile, 143(3), 320-328. doi: 10.4067/S0034-98872015000300006

Wood, A. M., Boyce, C. J., Moore, S. C., \& Brown, G. D. (2012). An evolutionary based social rank explanation of why low income predicts mental distress: A 17 year cohort study of 30,000 people. Journal of Affective Disorders, 136(3), 882 888. doi: 10.1016/j.jad.2011.09.014

Wu, H., \& Leung, S. O. (2017). Can Likert scales be treated as interval scales? -A Simulation study. Journal of Social Service Research, 43(4), 527-532. doi: $10.1080 / 01488376.2017 .1329775$ 